\title{
The Importance of Construction Services in Socio-Economic Development of the Region
}

\author{
Ismailov Adhambek Bakhramovich, Kuziboev Bekhzod Hamidovich \\ Department of Tourism, Tourism and Economics Faculty, Urgench State University, Urgench City, Uzbekistan
}

Email address:

goodluck_0714@mail.ru (I. A. Bakhramovich)

\section{To cite this article:}

Ismailov Adhambek Bakhramovich, Kuziboev Bekhzod Hamidovich. The Importance of Construction Services in Socio-Economic Development of the Region. International Journal of Management and Fuzzy Systems. Vol. 4, No. 2, 2018, pp. 24-28.

doi: $10.11648 /$ j.ijmfs.20180402.13

Received: July 2, 2018; Accepted: July 13, 2018; Published: August 14, 2018

\begin{abstract}
The article shows the role of construction services in the socio-economic development of the region. And also the important recommendations on the future development for construction services in the region are given. Besides, in this paper the problems arising during the implementation of investment-construction projects are analyzed. Sustainable development of investment and construction spheres is a balanced increase in the scope of works for the reconstruction and renovation of facilities, based on the observance of the principles of complex systematic development, taking into account the requirements of energy and resource conservation, environmental safety, organizational and technical reliability and socio-political stability. The construction industry is experiencing that stage of activity, in which there is a need to change the organizational forms and methods of managing the construction process.
\end{abstract}

Keywords: Region, Construction Services, Infrastructure, Touristic Attractiveness

\section{Introduction}

It is vital to develop construction services in the condition of modernization of national economy and improvement of wealth of the population. Construction services have both social and economic aspects. On the one hand, making comfort it increases the quality of wealth of population, on the other hand, improving infrastructure it encourages touristic attractiveness. A set of functionally interrelated specialized economic activities forms a "Construction complex" for functional feature. The criterion of structuring is adopted orientation of a group of interrelated industries (types of economic activity) to a large final public need. Thus, the construction complex is an integrated set of enterprises engaged in related economic activities, characterized by close economic, technical and technological links and functional unity in obtaining the final result - the reproduction of the passive part of the fixed assets of production and non-production, mainly to territory of the region.

On this occasion, the government are paying great attention to development of construction services. Particularly, the order of President "The strategies of movements on further development of The Republic of Uzbekistan" highlights issues on development and modernization of road-transportation, engineeringcommunication and social infrastructures, which improves lifestyle of the population [1].

In 2017 the growth of the amount of constructions was marked as 5.6 percent with 34060.8 billion soum according to building objects such as blocks of flats, houses, engineering and transport communication also social infrastructure. The share of construction in GDP was 6.8 percent [2].

In the proclamation to members of Senat and law chambers of Oliy Majlis, the President of The Republic of Uzbekistan Sh. M. Mirziyoev confirmed that it is planned to build new roads, to develop transport-logistic infrastructure, to improve services that are being served and also to expand to build cheap houses in 2018 more than 1.5 times [3].

All components of the production capacity of the construction organization cannot function without financial, regulatory and information support.

Financial provision in supporting the economic processes of the organization with the necessary financial resources.

The regulatory and legal support for the operation of the 
production potential includes legislative acts, orders, regulations, rates, tariff rates, guidelines and other regulatory documents of government bodies.

Information support consists of various types of economic, commercial, financial and other information, i.e. from circulating information flows.

The production potential of a construction company is determined by:

1) the volume and quality of the resources available to it (labor, basic production and non-productive, working capital, material stocks, intangible, technical resources, etc.);

2) abilities of employees to create planned products, i.e. the conformity of the complexity of work with their physical, educational, qualification, psychophysiological and motivational data;

3 ) the ability of the manager to optimally (rationally) using the existing production resources of the organization;

4) innovative abilities (ie the organization's ability to renew production, change technology, etc.);

5) information capabilities (ie the ability to process and analyze information for use in production);

6) Financial abilities (solvency of the organization, internal and external debts), etc.

In construction, a comprehensive accounting and evaluation of all the resources available to the construction organization, as well as the market needs for various types of construction products and services, should be established.

At the same time, the main task is to determine the balance of the production capacities of the enterprise, their current, promising market demand. This approach is the basis for the formation and development of the organization, since it takes into account the internal production capacities of the potential, the situation in the market environment and the trend of market development. In addition, the construction industry is a promising industry, with its progressive development.

\section{Methodology and Method}

According to I. S. Abdullayev's views, scientist in economics from Uzbekistan, during the period 2017-2020 in Khorezm, average annual figures of growth in construction sphere will be 9-10 percent [3]. Soviar, Jakub, Martin Holubčík, and Josef Vodáks studied cooperation management on construction business in case study of Slovak Republic [4] c. According to the appearance of the cooperation environment in the construction business was related to certain criteria, in relation to which were formed cooperation relationships, thus creating the cooperation environment [4]. Researcher who wrote the article on "Analysis construction industry on the basis of price trends of labor cost" [5] mentioned that the analysis of price trends of labor cost estimate in the construction industry had been divided into three research stages. Trends in the average net rate across the country (paragraph 2.2.) were analyzed in terms of general construction works: investment and renovation works as well as sanitary and electrical installation works. The study of national rate covered the period from the fourth quarter of 2009 to the first quarter of 2016, broken down into the aforementioned assortment of works [6]. Researchers Weil and David studied another factor of construction services. In their works they used data on existing wages and benefits and the costs of typical contractors in the industry and the business demands facing future contractors to speculate on what models of business organization might become dominant [7]. Paper by Raftery, John illustrates dilemma with the case of Japan as a world leader in international construction services. Its dominance has apparently come through the orchestration of industrial and corporate policies, implemented in a highly regulated and protected domestic market [8]. There are also a lot of works in this area: Yang, Jyh-Bin, and Sheng-Chi Peng [9], Arditi, David, and Larry Davis [10], Chen, Le, and Sherif Mohamed [11], Riley, D., Pexton, K. and Drilling [12], Shen, Weiming [13], Yisa, Silas B., Issaka Ndekugri, and Brian Ambrose [14] are some of them.

\section{Results and Discussion}

Widely distributed target principle of forming the composition of the construction complex, which includes:

a) construction and installation, repair and construction enterprises of different subordination ("construction industry");

b) industrial enterprises for the production of building structures, products, parts;

c) industrial enterprises of building materials;

d) enterprises for the production of construction and road machinery and tools for construction;

e) production infrastructure, construction of transport, communications, etc.;

f) design and survey organizations.

The main component of the construction complex is the construction industry - enterprises that directly carry out construction work on the basis of the intra-industry specialization of works on the installation of structures and parts; technical, electromechanical sanitary-technical and other types of special equipment.

It's important to introduce the concept of an innovative investment-building project as a complex of appropriately organized measures that ensure the solution of a specific scientific and technical problem leading to innovation. Within the framework of the innovative investment and construction project, the production, scientific and technical, financial, commercial, organizational and other activities coordinated in terms of time, resources and performers are performed. The mandatory property of innovation is scientific and technical novelty. At the same time, we consider the "novelty" of innovations to be appropriate for assessing both the technological parameters and the market positions [15].

A great deal of attention is paid to the development of 
construction services in Khorezm region of the Republic of Uzbekistan. The share of construction services in GRP was
1270.8 billion sum that is proof of our work (Table 1$)$.

Table 1. The main macroeconomic indicators of Khorezm in 2017 [16].

\begin{tabular}{llll}
\hline No & Indicators & billion sum & in percent comparison with 2016 \\
\hline 1 & Gross regional product & 8232.9 & 104.5 \\
2 & Industrial product & 3828.0 & 115.5 \\
3 & Products of consumption & 2291.7 & 108.6 \\
4 & Agriculture. forestry. fishery economy & 3780.6 & 100.1 \\
5 & Investments to main capital & 1677.1 & 113.9 \\
6 & Construction & 1270.8 & 100.0 \\
7 & Cargo turnover (mln. to-km) & 605.1 & 106.2 \\
8 & Passanger turnover (mln. passanger-km) & 7132.0 & 102.2 \\
9 & Retail sell turnover & 3925.1 & 100.1 \\
10 & Services in total & 3552.1 & 105.3 \\
11 & Foreign trade turnover (mln. USD) & 252.9 & 116.7 \\
12 & Export (mln. USD) & 120.2 & 125.8 \\
13 & Import (mln. USD) & 132.7 & 109.6 \\
14 & Net export (+;-) (mln. USD) & -12.5 & $\mathrm{X}$ \\
\hline
\end{tabular}

Table 2. The structure of construction works on the form of ownership [16].

\begin{tabular}{llll}
\hline \multirow{2}{*}{ o } & \multirow{2}{*}{ Indicators } & Years & \\
\cline { 3 - 4 } & & $\mathbf{2 0 1 6}$ & $\mathbf{2 0 1 7}$ \\
\hline 1 & $\begin{array}{l}\text { Construction works, billion sum } \\
\text { including: }\end{array}$ & 1220.9 & 1270.8 \\
2 & Government & 146.7 & 296.6 \\
3 & Non-government & 1074.2 & 974.2 \\
\hline
\end{tabular}

Construction works cost 974.2 billion sum were carried by non-government organisations and it is estimated as 92.9 percent of total construction size (in comparison with 2016, the figure of growth is 97.3 percent) (Table 2).

80.3 percent of total construction works is related with buildings and constructions, 14 percent with building civil objects and 5.7 percent with specialized construction works. Also, 78.9 percent of total size is related with new construction, rebuilding, expanding and re-equipping [16].

High growth rates of construction works were observed in the following regions: $103.5 \%$ in the Republic of Karakalpakstan and $11.4 \%$ over the previous year, respectively, in Navoi region - $103.0 \%$ (2.3\%), In the city of Tashkent, 110.9\% (6.1\%)[16].

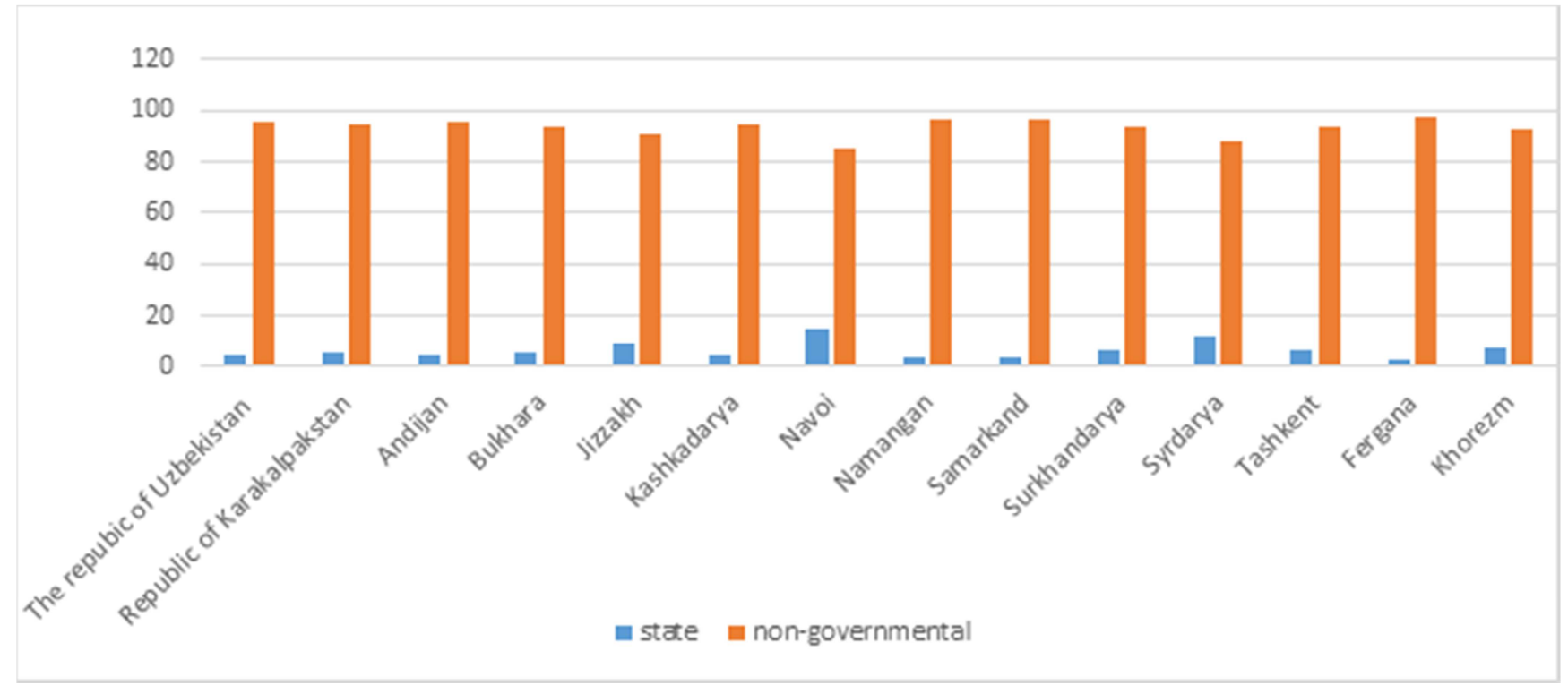

Figure 1. Construction works. Dates by The state committee of the Republic of Uzbekistan on statistics.

Generally, although construction services have developed much in the region recently, there are still several drawbacks in the sector that must be solved:

a. mainly, employees working in the construction sector are lack of modern skills and knowledge;

b. construction technologies are out of date, lack of contemporary ones;

c. the high level of import of construction materials and the rate of localization is low;

d. export of construction services has not been well organized;

e. lack of attention to build modern touristic attractions and skyscrapers. 
Due to those problems below, in my opinion, the recommendations below can contribute to development of construction services:

a. so as to teach workers engaged in construction sphere with foreign practice it is necessary to organize to send them to short courses abroad, also it is useful to call for popular foreign construction companies' experts to conduct seminars and master-classes in the region;

b. it is important to import techniques that may be helpful in building multistory houses;

c. localization process of construction materials must be under attention in the region. It will be important factor that decreases import in foreign trade of the region;

d. the share of construction services is estimated with 0 in export sphere of the region. Construction services should be actively advertised in the regional markets. Ancient-architecture construction services ought to play dominant role in export;

b. -the whole infrastructures of the region must be modernized with contemporary sights. Because, it is required to develop all infrastructures in complex way in order to attract foreign tourists.

\section{Conclusion}

In modern conditions, the problem of justifying the effectiveness of innovations in the construction industry is becoming particularly relevant for the development of Uzbekistan's construction industry and the reform of its economic mechanism, with a focus on market models of economic development and the introduction of modern innovative technologies. At the same time, it should be noted that at the legislative level up to the present time, when forming and implementing capital construction projects, there is no right of demand and assistance from the public authorities to the developer to create innovative products, to provide the appropriate level of services. It should be noted that if the financial indicators of project evaluation are more or less clear, then with the level of innovation, everything is much more difficult, despite the fact that the requirements for innovativeness of the implemented projects are included in the Strategy for Innovative Development of Uzbekistan. The above analysis shows that in international and Uzbek practice there are many approaches to assessing innovation, but they can not be considered universal and are applied differentially depending on the goals and objectives of using the results of scientific achievements in the form of intellectual property to improve the efficiency and competitiveness of industries, products, services. At the same time, an individual, specific assessment method is chosen and implemented, based on taking into account all legal, economic, technical and other aspects.

To implement the recommendations above encourages the development of service sector and construction services in the region. Consequently, the region`s infrastructure will be improved, the number of tourists will increase and receipts of foreign currency will grow. All these trends will lead regional economy to progress and cause population`s income to surge.

\section{References}

[1] The order of the President of the Republic of Uzbekistan "The strategies of movement on further development of Uzbekistan” № 4947, 07.02.2017.

[2] Dates by the state committee of the Republic of Uzbekistan on statistics.

[3] Sh. M. Mirziyoev`s proclamation to members of Senat and law chambers of Oliy Majlis, the President of The Republic of Uzbekistan. 22.12.2017 www.gov.uz.

[4] Abdullayev I. S. Improving optimal regulating mechanisms of regional economic system. Doctoral dissertation abstract on economic sciences.-Tashkent: TSUE, 2017 -66 pages.

[5] Soviar, Jakub, Martin Holubčík, and Josef Vodák. "Cooperation Management on Construction Business Market in the Slovak Republic-an Insight from a Company." Procedia Engineering 192 (2017): 818-823.

[6] Przywara, Daniel, and Adam Rak. "Analysis construction industry on the basis of price trends of labor cost." MATEC Web of Conferences. Vol. 174. EDP Sciences, 2018.

[7] Weil, David. "A green industrial relations system for construction: Challenges and opportunities." Members-only Library (2018).

[8] Raftery, John, et al. "Globalization and construction industry development: implications of recent developments in the construction sector in Asia." Construction Management \& Economics 16.6 (1998): 729-737.

[9] Yang, Jyh-Bin, and Sheng-Chi Peng. "Development of a customer satisfaction evaluation model for construction project management." Building and Environment 43.4 (2008): 458-468.

[10] Arditi, David, and Larry Davis. "Marketing of construction services." Journal of Management in Engineering 4.4 (1988): 297-315.

[11] Chen, Le, and Sherif Mohamed. "China's foreign economic cooperation development: Exporting Chinese construction services." CIB W107 1st International Conference on Creating a Sustainable Construction Industry in Developing Countries. Division of Building and Construction Technology, CSIR, 2002.

[12] Riley, D., Pexton, K. and Drilling, J., 2003. Procurement of sustainable construction services in the United States: the contractor's role in green buildings. Industry and environment, 26 (2), pp.66-69.

[13] Shen, Weiming, et al. "Systems integration and collaboration in architecture, engineering, construction, and facilities management: A review." Advanced engineering informatics 24.2 (2010): 196-207.

[14] Yisa, Silas B., Issaka Ndekugri, and Brian Ambrose. "A review of changes in the UK construction industry: their implications for the marketing of construction services." European Journal of Marketing 30.3 (1996): 47-64. 
[15] Sukhachev K. A., Sultanova I. P., Dolzhenko Yu. A. Novye technology upravleniya kak sredstvo resheniya problem stroitel'stva energeticheskikh ob"ektov [New Management Technologies as Means of Solving the Problems of Energy Facilities Construction]. Neftegazopromyslovyy inzhiniring [Oil and Gas Engineering]. 2013, Special issue no. 7, pp. 6266. (In Russian).
[16] Dates by the state committee of the Republic of Uzbekistan on statistics. 